available for the serosal transfer step of the transport mechanism; third, a DNA-mediated inhibitor of the second step of the iron transport is produced which decreases the serosal transfer of iron. Mice with the mutant gene, sla, offer an important system for testing these hypotheses as well as for studying the biochemistry of the active transport mechanism for iron in the intestinal mucosa of the mouse.

I thank Professor D. S. Falconer and Dr J. Dancis (New York University School of Medicine) for giving me the sla breeding stock and Miss V. Jansen (New York University School of Medicine) for advice on breeding. This work was supported by the US National Institutes of Health.

Department of Medicine,

Hospital for Joint Diseases and Modical Center,

New York, New York 10035.

Received January 9, 1970.

I Falconer, D. S., and Isaacson, J. H., Genet. Res. Camb., 3, 248 (1962). 2 Pinkerton, P. H., and Bannerman, P. M., Nature, 216, 482 (1967).

3 Manis, J. G., and Schachter, D., Amer. J. Physiol., 203, 73 (1962).

- Biology of the Laboratory Mouse (edit. by Green, E. L.), second ed., 352 (McGraw-Hill, New York).

- Manis, J. G., and Schachter, D., Amer. J. Physiol., 203. 81 (1962).

\section{Distribution of $\mathrm{HbCO}$ in Human Erythrocytes following Inhalation of $\mathrm{CO}$}

The distribution of carbon monoxide in erythrocytes of persons exposed to high concentrations of gas for short periods was investigated using a modification of the staining technique described by Betke and Kloihauer ${ }^{1}$. The experiments consisted of examination of citrated human blood carboxylated with pure $\mathrm{CO}$ and thon decarboxylated with oxygen, and capillary blood taken at intervals following inhalation of $\mathrm{CO}$ as the pure gas or from tobacco smoke.

Tho mothod used in this study was as follows: $50 \mu \mathrm{l} .1 \cdot 25$ per cent $w / v$ aqueous sodium nitrite was mixed with $50 \mu \mathrm{l}$. blood and stood under nitrogen for $10 \mathrm{~min}$.; $50 \mu \mathrm{l}$. 1 per cent $\mathrm{w} / \mathrm{v}$ aqueous potassium cyanide was then added and the mixture was then left for $1 \mathrm{~min}$. Thin, even smears wore prepared and the slides were stood vertically without shaking in a freshly prepared mixture of $80 \mathrm{ml}$. 96 per cent ethanol, $16 \mathrm{ml} .0 \cdot 2 \mathrm{M}$ citric acid and $5 \mathrm{ml} .30$ per cent hydrogen peroxide for $3 \mathrm{~min}$. They were then washed in methanol and stained in 0.05 per cent $\mathrm{w} / \mathrm{v}$ aqueous gentian violet for 1 min. The slides were examined by light microscopy with a green filter.

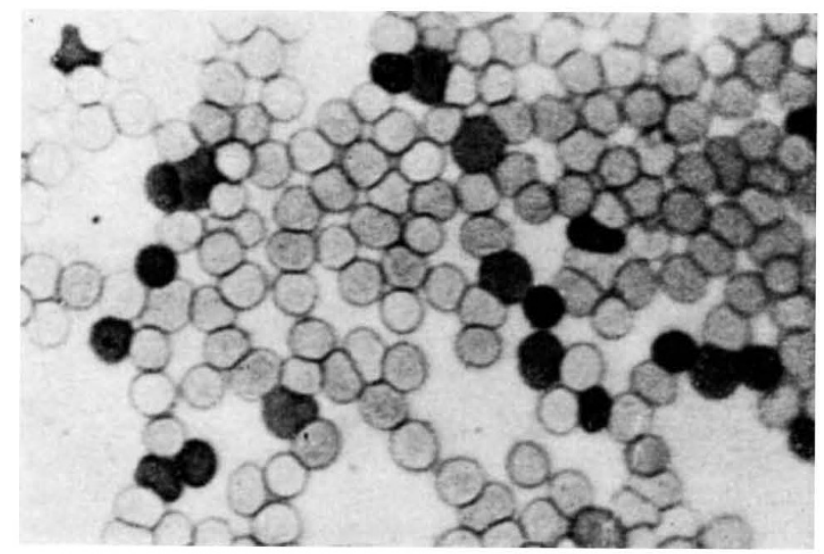

Fig. 1. Photomicrograph showing human erythrocytes stained for the presence of carboxyhaemeglobin in peripheral blood $1 \mathrm{~h}$ after inhalation

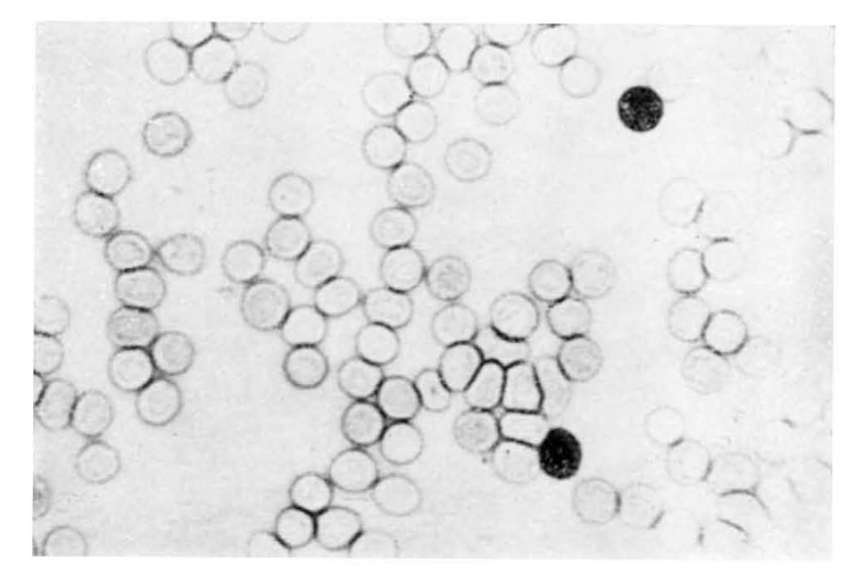
Fig. 2. Photomicrograph showing human erythrocytes from peripheral
blood of a pipe smoker stained for the presence of carboxyhaemoglobin.

It was observed that when 100 per cent $\mathrm{CO}$ was passed into human citrated blood for varied times, carboxylation did not affect all erythrocytes in the same manner. At low concentrations of carboxyhaemoglobin, few cells showed any staining, but those that did were more densely stained at the periphery than at the centre. As the uptake of $\mathrm{CO}$ proceeded the proportion of stained cells increased, as did the evenness of staining, until full carboxylation was observed. Staining started at the periphery and increased gradually until the whole cell was stained. On passing oxygen through the carboxylated blood the reverse was noted with the cells losing stain from the periphery leaving a more intensely stained centre. Individual cells lost stain at different rates. It was also observed that whereas uptake of $\mathrm{CO}$ by erythrocytes took place rapidly, the complete decarboxylation process took several hours.

Experiments in vivo consisted of a study of capillary blood samples taken $1 \mathrm{~h}$ after inhalation of $500 \mathrm{ml}$. of pure $\mathrm{CO}$ and from persons who were both eigarette and pipo smokers. Fig. $\mathbf{l}$ is a photomicrograph of capillary blood taken $1 \mathrm{~h}$ after inhalation of the pure gas. The blood sample was stored at $4^{\circ} \mathrm{C}$ for $96 \mathrm{~h}$ before staining. It can be seen that the rapid redistribution of $\mathrm{O}_{2}$ and $\mathrm{CO}$ between erythrocytes at $37^{\circ} \mathrm{C}$ reported for experiments in vitro ${ }^{1}$ had not occurred, either during body circulation or during storage of the sample. When tobacco smoke is inhaled the picture is initially similar with the stained cells having dark peripheries; as normal smoking continuos throughout the day the picture alters with a mixed stained cell population appearing, the majority of the cells now having more intensely stained centres as decarboxylation of the individual erythrocytes proceeds. Fig. 2 is a photomicrograph of capillary blood taken at $1600 \mathrm{~h}$ from a pipe smoker who had smoked freely since $0900 \mathrm{~h}$. Comparison of the proportion of the types of stained cells undergoing carboxylation and decarboxylation in such a preparation gives an indication of the time that has elapsed since inhalation of CO. These observations suggest that: (1) following inhalation of $\mathrm{CO}$ only the erythrocytes exposed to the gas in the lungs are carboxylated; (2) redistribution of the carboxyhaemoglobin between erythrocytes during subsequent circulation does not occur; (3) the hypoxic insult to an individual erythrocyte will not be related to the carboxyhaemoglobin saturation as determined on whole blood.

D. J. BLACKMORE *

RAF Institute of Pathology and Tropical Medicine,

Halton, Aylesbury, Buckinghamshire.

Received December 23, 1969.

* Present address: Home Offlce Central Research Establishment, Aldermaston, Berkshire.

${ }^{1}$ Betke, K., and Kleihauer, E., Nature, 214, 188 (1967). 